\title{
Meta-analysis of survey data to assess trends of prairie butterflies in Minnesota, USA during 1979-2005
}

\author{
Dennis Schlicht $\cdot$ Ann Swengel $\cdot$ Scott Swengel
}

Received: 6 May 2008/ Accepted: 20 October 2008/Published online: 25 November 2008

(C) The Author(s) 2008. This article is published with open access at Springerlink.com

\begin{abstract}
During 1993-1996, two teams (Schlicht, Swengels) surveyed the same Minnesota prairies, but without any coordination of sites, routes, methods, dates, and results between teams. In 27 instances, both teams surveyed the same site in the same year between 30 June and 18 July. For the 18 most frequently recorded species, abundance indices (individuals $/ \mathrm{h}$ per site) significantly covaried between teams for $11(61 \%)$ species, including $2 / 3$ prairie specialists tested. No species significantly correlated negatively, 17/18 species had positive correlations, and the preponderance of positive correlations was significant. Swengel indices per hour (two surveyors; unlimited-width transect) averaged 2.42 times Schlicht indices (one surveyor; fixed-width transect). These results demonstrate that transect surveys by different teams at the same sites but not the same routes produce similar rankings of species abundance among sites. This approach to population monitoring (transect surveys during the season that covers the most specialist species at once, not necessarily with fixed routes but recording all species seen) might also be appropriate in other regions with high habitat loss and low human population density. Abundance indices from surveys by seven teams spanning 1979-2005 were calculated for evaluating population trends. For the five analyzable specialist species, 25/30 population trend tests of a species at a site had a negative direction, a highly significant skewing $(P<$ 0.0001). By contrast, five "common" (most frequently
\end{abstract}

D. Schlicht

Iowa Lepidoptera Project, 1108 First Avenue, Center Point, IA 52213, USA

A. Swengel $(\bowtie) \cdot S$. Swengel

909 Birch Street, Baraboo, WI 53913, USA

e-mail: swengel@naba.org recorded non-specialist) species had an even distribution of negative and positive trends. While adjacent sites had similarly timed decline thresholds (last year when a higher rate or any individual was recorded vs. first year when all subsequent indices were lower or zero) within species, these thresholds were not synchronized among sites in different counties. All sites analyzed in this study were preserves managed primarily with fire. While the ecosystem (or vegetative) approach to reserve selection has been validated in other studies to be effective at capturing populations of associated specialist butterflies, butterfly declines after reserve designation will likely continue unless the ecosystem approach to reserve management includes specific consideration of individual butterfly species' required resources and management tolerances.

Keywords Atrytone arogos iowa Hesperia dacotae. Hesperia ottoe - Oarisma poweshiek · Speyeria idalia . Specialist butterflies Prairie management

\section{Introduction}

Surveying and monitoring are necessary components of conservation programs, both to identify those species (of the ones effectively sampled) that do and do not require conservation action, and to assess the efficacy of conservation actions (Dennis 1993; Pollard and Yates 1993). Butterfly abundance varies greatly among broods attributable to fluctuations in abundance due to climate and other factors (Dennis 1993; Pollard and Yates 1993). As a result, long-term monitoring is necessary to assess a butterfly species' status and trend (Thomas et al. 2002). In England, weekly counts have occurred long-term on fixed routes, with results among trained observers validated to be 
functionally similar (Pollard and Yates 1993). Many European countries have similar programs (van Swaay and van Strien 2005). These are rigorous monitoring programs, but such data are not available for Minnesota, USA due to limitations of resources and personnel. To obtain long-term data, survey results from different teams using different methods must be evaluated. An underlying premise of most butterfly status/trend assessments is that data from different or informal (variable) methodologies can be pooled in some manner (Saarinen et al. 2003; Shuey 2005; van Swaay and van Strien 2005; van Swaay et al. 2006; Kuussaari et al. 2007).

At the more informal end of the spectrum are collector/ observer records. Such presence/absence records are a function of effort just as abundance indices are (Dennis et al. 1999; Dennis and Thomas 2000), but it is difficult to assess what locations were visited and when, if only positive data are available. Studies may correct for this bias (Dennis et al. 1999), not correct for this after determining it to be a minor error in the analyzed dataset (Saarinen et al. 2003), not correct or test for this bias (Parmesan 1996; Komonen 2007), or conclude that the data can't be interpreted (Swengel and Swengel 2001a). The datasets in this meta-analysis are more rigorous than collector/observer records, in that date, effort (hour or $\mathrm{km}$ of surveying, or both), number of surveyor(s), and surveyed species (found or not) are known for the available datasets, and often weather conditions, time of day, and route location. Nonetheless, unquantified sources of variation (e.g., differences in exact survey route, although location at the scale of site is controlled) are potential sources of error in this study, requiring more care in interpreting the results.

During 1993-1996, two teams-Schlicht (one surveyor) and Swengels (two surveyors) - happened to survey the same Minnesota prairies at much the same time in the same years, but without any coordination of survey sites, transect routes, survey methods, survey dates, and results between the teams. In this paper, butterfly abundance indices were tested for correlation between the two teams at the scale of the site and the subsite. Since strong covariance occurred, thus establishing a validation of data pooling, a calibration of the indices between the two teams was then conducted. Abundance indices of prairie-specialist butterfly species in western Minnesota prairies were then calculated for longterm monitoring during 1979-2005 ("monitoring" defined here as a time series of population indices used to calculate trend), using not only Schlicht and Swengel surveys but also publicly available data from five other teams. Statelisted butterfly and day-flying moths occurring in western Minnesota prairie (Table 1) are a conservation concern primarily because of vast prairie destruction $(99.6 \%$ in Minnesota) due to conversion to intensive agriculture and urbanization (Samson and Knopf 1994), as well as isolation, degradation, and unfavorable land use/management of remaining conserved and unconserved tracts (McCabe 1981; Dana 1991; Schlicht 2001). As a comparison, long-term monitoring indices were also calculated for the five most abundant butterflies in these surveys. The goals of the individual teams' studies were to assess the status of these prairie-specialist species and to document their habitat and management preferences. The goals of this meta-analysis were to assess the comparability of data among teams, so as to determine whether and how the teams' data could be aggregated to analyze status and trend of key species in major reserves.

\section{Methods}

Surveys

Two teams conducted transect butterfly surveys in summer in Minnesota: Schlicht during 1993-1997 and 2000 (Schlicht 1997a, b; Schlicht and Saunders 1993, 1995; Schlicht 2001, 2003) and Swengels during 1988-1997 (Swengel 1996, 1998; Swengel and Swengel 1999a). Numbers of all butterfly species and diurnal Schinia moths were recorded (see Tables 1 and 2 for scientific names). Special effort was made to identify and survey habitat of target species: for Schlicht, primarily Dakota skipper but also regal fritillary, Poweshiek skipperling, and Arogos and Ottoe skippers ("midsummer specialists"); for Swengels, those same species plus "late-summer specialists" (Leonard's and common branded skippers). "Specialist" is defined as restricted, or nearly so, to native prairie vegetation, being sensitive to vegetative degradation (Swengel 1998; Schlicht et al. 2007). The target species were selected because these specialists were particularly restricted in their requirements and/or range, and were of particular conservation concern, e.g., having a legal status in the study region (Table 1, Coffin and Pfannmuller 1988).

Methods were similar between the two teams (e.g., both teams used binoculars for identification), with these differences. Schlicht included within survey time the collection of voucher specimens, net-and-release identification, and recording of wing wear of target species, while Swengels did not use nets, vouchered with photography but deducted that from survey time, and recorded nectar visits and behavior of targets. Schlicht used a transect $10 \mathrm{~m}$ wide; Swengels an unlimited width. Where routes were marked on a topographic map in the Schlicht survey reports, distance surveyed was measured from the map for analysis here. Swengels estimated distance surveyed at the time of each survey, based on site maps and landmarks of known distance apart. Schlicht surveys conducted by 1-3 surveyors; when one, occasionally the surveyor wasn't Schlicht. 
Table 1 Butterfly and dayflying moth species inhabiting prairie in western Minnesota with a legal conservation status in Minnesota (MDNR 2007b)

${ }^{\mathrm{a}} \mathrm{SC}=$ special concern,

$\mathrm{T}=$ threatened,

$\mathrm{E}=$ endangered

b Recently proposed as special concern but not enacted in the revision of the state list (MDNR 2007a, b)

\begin{tabular}{lll}
\hline Status $^{\mathrm{a}}$ & Species & Family \\
\hline $\mathrm{SC}$ & Regal fritillary (Speyeria idalia) & Nymphalidae \\
$\mathrm{E}$ & Uhler's arctic (Oeneis uhleri varuna) & Nymphalidae \\
$\mathrm{SC}$ & Poweshiek skipperling (Oarisma poweshiek) & Hesperiidae \\
$\mathrm{T}$ & Garita skipperling (Oarisma garita) & Hesperiidae \\
$\mathrm{E}$ & Uncas skipper (Hesperia uncas) & Hesperiidae \\
$\mathrm{E}$ & Common branded (Assiniboia) skipper $($ H. comma assiniboia) & Hesperiidae \\
$\mathrm{T}$ & Ottoe skipper (Hesperia ottoe) & Hesperiidae \\
$\mathrm{SC}$ & Leonard's skipper (Hesperia leonardus) & Hesperiidae \\
$\mathrm{T}$ & Dakota skipper (Hesperia dacotae) & Hesperiidae \\
$\mathrm{SC}$ & Arogos skipper (Atrytone arogos iowa) & Hesperiidae \\
$\mathrm{SC}$ & Phlox moth (Schinia indiana) & Noctuidae \\
& Leadplant moth (Schinia lucens) & Noctuidae \\
\hline
\end{tabular}

Table 2 Spearman rank correlations of Schlicht and Swengel population indices (individuals $/ \mathrm{h}$ ) of 18 most recorded species $(*=$ prairie specialist) in 27 visits to the same 14 sites surveyed in the same years (1993-1996) in midsummer (30 June to 18 July)

\begin{tabular}{|c|c|c|c|c|c|c|c|}
\hline $\operatorname{Codes}^{\mathrm{a}}$ & Species & $N$ site-pairs ${ }^{\mathrm{b}}$ & $N$ individuals $^{\mathrm{c}}$ & $\begin{array}{l}\text { Percent zero } \\
\text { Indices }^{\mathrm{d}}\end{array}$ & $\begin{array}{l}\text { Percent mismatched } \\
0 \text { Indices }^{\mathrm{e}}\end{array}$ & $r$ & $P$ \\
\hline 2,2 & Silver-bordered fritillary (Boloria selene) & 27 & 93 & 87.0 & 25.9 & -0.147 & $>0.10$ \\
\hline 1,2 & Regal fritillary & 27 & 95 & 57.4 & 48.1 & +0.022 & $>0.10$ \\
\hline $1,1, \mathrm{~m}$ & Orange sulphur (Colias eurytheme) & 27 & 50 & 70.4 & 51.9 & +0.110 & $>0.10$ \\
\hline 2,1 & Delaware skipper (Anatrytone logan) & 27 & 30 & 87.0 & 18.5 & +0.195 & $>0.10$ \\
\hline 1,2 & Common ringlet (Coenonympha tullia) & 27 & 36 & 77.8 & 29.6 & +0.247 & $>0.10$ \\
\hline 1,1 & Great spangled fritillary (Speyeria cybele) & 27 & 127 & 75.9 & 25.9 & +0.353 & $<0.10$ \\
\hline 1,2 & Northern brown (Enodia anthedon) & 26 & 75 & 84.6 & 23.1 & +0.362 & $<0.10$ \\
\hline 1,2 & Aphrodite fritillary (Speyeria aphrodite) & 27 & 94 & 74.1 & 22.2 & +0.413 & $<0.05$ \\
\hline 2,1 & Long dash (Polites mystic) & 27 & 194 & 46.3 & 40.7 & +0.457 & $<0.05$ \\
\hline $2,1, \mathrm{~m}$ & Pearl crescent (Phyciodes tharos ${ }^{f}$ ) & 27 & 159 & 70.4 & 22.2 & +0.470 & $<0.05$ \\
\hline 2,1 & Meadow fritillary (Boloria bellona) & 27 & 88 & 77.8 & 22.2 & +0.497 & $<\mathbf{0 . 0 1}$ \\
\hline $2,2, \mathrm{~m}$ & Melissa blue (Lycaeides melissa) & 27 & 43 & 72.2 & 25.9 & +0.498 & $<0.01$ \\
\hline 1,1 & Common wood-nymph (Coenonympha tullia) & 24 & 2196 & 25.0 & 16.7 & +0.604 & $<0.01$ \\
\hline $1,1, \mathrm{~m}$ & Clouded sulphur (Colias philodice) & 27 & 140 & 40.7 & 22.2 & +0.698 & $<0.01$ \\
\hline 1,1 & Black swallowtail (Papilio polyxenes) & 27 & 42 & 88.9 & 7.4 & +0.733 & $<0.01$ \\
\hline 2,2 & Dakota skipper* & 27 & 445 & 46.3 & 11.1 & +0.793 & $<0.01$ \\
\hline 2,2 & Poweshiek skipperling* & 27 & 797 & 51.9 & 22.2 & +0.796 & $<0.01$ \\
\hline $1,1, \mathrm{~m}$ & Monarch (Danaus plexippus) & 27 & 67 & 74.1 & 7.4 & +0.816 & $<0.01$ \\
\hline
\end{tabular}

${ }^{a}$ Codes: detectability code $(1=$ large and easy to identify; 2 = small and/or hard to identify), followed by encounterability code ( 1 = widespread, uses many vegetation types, $2=$ localized or restricted, uses only a few vegetation types); $\mathrm{m}=$ multiple-brooded with overlapping generations

${ }^{\mathrm{b}}$ Site-pair = site surveyed by both teams in same year (missing site-pairs occurred when species was recorded as present but not quantified)

c Total individuals recorded by both teams combined (all species with $>29$ individuals included)

d Total number of zero indices, combined for both teams, as a percent of total indices analyzed (two times $N$ site-pairs)

e Total number of site-pairs where one team found 0 but other team found $>0$, as a percent

${ }^{\mathrm{f}}$ Includes Phyciodes selenis, if recorded

Swengels conducted all surveys together on parallel separate transects about $10 \mathrm{~m}$ apart. Schlicht used a stricter protocol for time of day and weather than Swengels. Schlicht used or adapted loop routes mapped by Minnesota Department of Natural Resources (MDNR) personnel, and for 1995-1996, the straight line transects previously established at Prairie Coteau by Selby (Selby and GlennLewin 1989, 1990) and elsewhere, typically straight line transects with landmarks marking the start, end, and turns. Swengels followed routes (rarely straight lines) they 
established in previous years, but sometimes added or omitted units; each unit contained vegetation relatively similar in type, quality (based on amount of brush and diversity and abundance of native and non-native flora), and management. Schlicht resurveyed some sites to provide broader coverage of the target species' varying flight periods (time when a butterfly species is in the adult life stage); the late June-July sampling period was 14-25 days long per year 1993-1997. Swengels sampled in shorter periods (2-4 days each year in June 1988-1989, 1-3 days twice in June 1990, 3-6 days each year in July 1990-1997, 4-5 days each year in August 1991-1993) and resurveyed within period only due to weather. While a number of factors varied between the Schlicht and Swengel teams, the primary differences in survey methods were in transect width (10 m vs. unlimited), number of surveyors (typically one vs. always two), length of survey period (14-25 days vs. 1-6 days), and route location.

\section{Overview of analyses}

Butterfly population indices were calculated as individuals per survey time $(\mathrm{h})$ or distance $(\mathrm{km})$ to create an observation rate (relative abundance). The Spearman rank correlation was used for all correlations, the Wilcoxon signed ranks test for all tests for differences between paired samples, the Mann-Whitney U test for all tests between two categories, and the binomial probability test for all tests for a preponderance of negative or positive correlation coefficients in a set of correlations (random distribution $=50 \%$ positive, $50 \%$ negative). All tests were two-tailed, with statistical significance set at $P<0.05$. Since significant results typically occurred at a frequency well above that expected due to spurious Type I statistical error, the critical $P$ value was not lowered further, as more Type II errors (biologically meaningful patterns lacking statistical significance) would be created than Type I errors eliminated. However, the samples of sites and $N$ years in this study were relatively small and an individual result can nonetheless be a Type I or Type II error. Due to the numerous statistical tests in this paper, greater confidence should be placed in patterns that recurred frequently with significance or consistent non-significance, as well as contrasts between different ecological groups of species. All statistics were calculated using ABstat 7.20 (1994 Anderson-Bell, Parker, Colorado, USA).

\section{Validation}

Correlation of indices between teams was analyzed separately at the site and subsite scales. A site is a named prairie, as in preserve guides (Wendt 1984; TNC 1988, 1994), except the original and new acquisitions at Hole-in-
the-Mountain Prairie were distinguished as two separate (but contiguous) sites when possible. The entire survey at a site on a single date by a team was used to calculate the index, regardless of whether and how much the routes overlapped between teams. A subsite consists of the minimum number of transect segments surveyed by Schlicht on a single date that can be cross-referenced to the minimum set of units surveyed on a single date by Swengels; e.g., one Schlicht segment might correspond to two Swengel units, or vice versa. All Schlicht surveys in these correlations were conducted by Schlicht alone.

In 27 instances, both teams surveyed the same site in the same year; $N=14$ sites during 1993-1996, with 1-3 years per site, in a total of $39.2 \mathrm{~h}$ (Schlicht) and $28.4 \mathrm{~h}$ (Swengels) of surveying between 30 June and 18 July. Within pair of site surveys by the two teams, survey date averaged 3.7 days apart (range 0-12 days). All species with a minimum of 30 individuals observed by both teams combined were analyzed. Indices both per hour and per $\mathrm{km}$ were available in 12 pairs of site surveys at 7 sites (in a total of $23.1 \mathrm{~h}$ and $41.7 \mathrm{~km}$ for Schlicht, $13.7 \mathrm{~h}$ and $26.4 \mathrm{~km}$ for Swengels); all species with a minimum of 15 individuals observed by both teams combined were analyzed. In 25 instances, both teams surveyed the same subsite in the same year; $N=15$ subsites of 5 sites during 1995-1996, with 1-2 years per subsite, in a total of $12.7 \mathrm{~h}$ and $25.1 \mathrm{~km}$ (Schlicht) and $8.1 \mathrm{~h}$ and $15.9 \mathrm{~km}$ (Swengels) of surveying during 1-13 July. Within pair of subsite surveys, survey date averaged 2.6 days apart (range $0-4$ days). All species with a minimum of 15 individuals observed by both teams combined were analyzed.

Several variables were tested for their relationship to the strength of these correlations between the two teams' indices. The correlation coefficients $(r)$ were tested for significant correlation with (1) total number of individuals recorded by both teams combined, (2) percent zero indices (out of all indices in sample, pooled for both teams), and (3) percent "mismatched zero" indices (i.e., one index in the pair was zero but the other positive). To test for whether results varied by type of index (per hour or per $\mathrm{km}$ ), correlations were calculated for both types of indices.

\section{Calibration}

To make indices between the two teams comparable, we conducted a calibration between Schlicht and Swengel indices. The mean index (separately per hour and per $\mathrm{km}$ ) per team was calculated for each species, separately at the site and subsite scales, using the data in the validation correlations. All the mean indices per species were then averaged to create a grand mean index for all species per team. The grand means were used to calculate a calibration constant between the two teams, separately at the site and 
subsite scales and separately per hour and per $\mathrm{km}$. This is not the calibration of transect surveys (relative abundance) to estimates of absolute abundance per Thomas (1983) and MacKenzie et al. (2005), as no pairings of transects to estimates were available matched by species, site, and year. Rather, this is a calibration of transect surveys to make indices comparable between the Schlicht team (one surveyor; fixed-width transect) and the Swengel team (two surveyors; unlimited-width transect).

A species-specific calibration was not used because sampling error would be greater, as well as variation among species due to true differences in observed numbers depending on exactly where each team surveyed (different areas in a site and differences in weather among dates might result in different observed butterfly densities) and phenological variation between the teams' surveys. The larger the sample (the more survey effort, and species and individuals observed), the more these confounding factors should average out.

To test for butterfly detection factors affecting betweenteam calibration for different species, a calibration-ratio was calculated by dividing the Swengel mean index by the Schlicht mean index for each species in the site-scale correlations. These ratios were tested for significant relationships to species' characteristics that might allow relatively more of a species to be recorded on an unlimited width transect by two surveyors than a fixed width by one, thus making the calibration ratio higher: e.g., larger butterflies can be recorded from further away, more localized species are more likely to be found in the wider strip. If one team's survey dates skewed earlier than the other's in these pairs of surveys, then the calibration-ratio would skew to the team surveying nearer to a species' peak timing. To check for effects of statistical power, the same variables (total individuals, percent zero indices, percent mismatched zero indices) in "Validation" (above) were tested for whether more individuals and fewer zero indices related to lower calibration-ratios.

Each species' size was calculated as the average of the minimum and maximum wingspan in Marrone (2002), Royer (2003), and Schlicht et al. (2007). Species were classified by "detectability": 1 for medium/large in size ( $>3.5 \mathrm{~cm}$ mean wingspan) and easy to identify $(N=10$ species) vs. 2 for small ( $<3.2 \mathrm{~cm}$ mean wingspan) and/or hard to identify ( $N=8$ species). The "encounterability" code used 1 for widespread species inhabiting many vegetation types and 2 for localized species restricted to a few vegetation types, based on Marrone (2002), Royer (2003), and Schlicht et al. (2007). Each species' codes for detectability and encounterability were summed as a "combination code": e.g., 2 is both more detectable and encounterable, 4 is both less detectable and encounterable. Survey date was tested for a significant difference between teams, and each species' phenology was classified by correlating each species' indices to date, separately by team. When both teams had a negative correlation coefficient vs. date, the species was classified as later in the adult brood; when both were positive, earlier in the adult brood; when sign differed between teams (always negative for Schlicht and positive for Swengel), the species was intermediate or indeterminate. Species were also classified as "multivoltine" (known to have multiple broadly overlapping generations per year) or not, per Schlicht et al. (2007).

Tests were performed on all species as well as subgroups, e.g., more vs. less detectable or encounterable species, including/excluding specialist species (as calibration ratios might be systematically lower for these due to both teams targeting them) or multivoltine species (which, with their overlapping generations, might have less phenological variation than species with distinct generations). Likewise, Dennis et al. (2006) analyzed the relationship of higher (or sooner) recorded butterfly numbers to variables similar to the ones here: wing length, brightness of coloration (cf. detectability code here), and length of flight period (cf. code for multivoltine species here), as well as other variables not feasible and/or not applicable to this study.

\section{Monitoring}

For each midsummer specialist, one index per year was identified to represent its abundance at a site, for sites with indices in main flight period for $>5$ different years, at sites surveyed in midsummer over a span of $>9$ years. These additional datasets were available: mark-release-recapture (MRR) surveys of Dakota and Ottoe skippers at Hole-inthe-Mountain in 1979-1981 by Dana (1991); transect surveys of the midsummer specialists (1988) and those and many other butterfly species (1989-1990) at Prairie Coteau by Selby (Selby and Glenn-Lewin 1989, 1990); surveys of all butterflies at various sites in 2003-2005 (Selby 2006) and regal fritillary, Poweshiek skipperling, and Dakota skipper by Skadsen at Glacial Lakes State Park in 2001 as reported in Selby (2006), with implication of similar routes by Skadsen and Selby (mean Selby distance per transect location was used for Skadsen's survey effort here); regal fritillary surveys at many sites in 1998-1999 by Mason (2001), and Dakota skipper data (Britten 2001; Britten and Glasford 2002).

Peak Schlicht indices per site per year for each species were designated as the standard to which other teams' indices needed to be made comparable. Thomas (1983) found that a single transect survey through core habitat of a butterfly during main flight period was adequate to generate effective, comparable population indices among sites. Likewise, time series of single peak transect survey indices 
covaried significantly between two teams, each surveying the federally endangered Karner blue (Lycaeides melissa samuelis) on different schedules in adjacent counties in Wisconsin (AB Swengel and SR Swengel 2005a).

These adjustments were made to other teams' indices to make them more comparable in survey effort to Schlicht's indices. Swengel indices were divided by the constant calculated in "Calibration." Whichever team had the highest index per site per year on a single date was used. Since only the Schlicht and Swengel teams surveyed the same sites in the same year, a calibration constant could only be calculated between these teams. Dana in litt. (5 March 1993) provided estimated ranges of individuals/h on the peak day per year for Dakota and Ottoe skippers excluding time spent on MRR. Since multiplying the individuals captured/h on the peak date each year 19791981 (Dana 1991: Figs. 13-14) by 2.5 reached the low end of his estimated range, that constant was used to calibrate all daily MRR capture rates (Dana 1991: Figs. 13-14) to Schlicht indices. Since Dana (1991) and Selby (Selby and Glenn-Lewin 1989, 1990) surveyed most days during their targets' flight periods, their peak date per year is likely a better approximation of peak than in the Schlicht and Swengel datasets. For their surveys in each species' main flight period (the 6-9 days provided in Dana 1991: Figs. 13-14; 8-19 day spans for 1989-1990 in Selby and Glenn-Lewin (1989, 1990), and 5 days in 1988 as surveys began partway through main flight period), the median (not peak) index was used. Since survey data on Arogos skipper and Poweshiek skipperling were not provided in Dana (1991), the minimum estimate from Dana in litt. (5 March 1993) was used for these species only for one year, designated as 1980 , and was divided in half to make these estimates conservative, even though Dakota skipper median indices averaged $88 \%$ of peak indices and $67 \%$ for Ottoe skipper for 1979-1981 (Dana 1991). In 1989, Selby surveyed one unit several times per day (Selby and GlennLewin 1989). As in Schlicht (2001, 2003), the survey started at $1200 \mathrm{~h}$ Central Standard Time was used here.

For Glacial Lakes 2003-2005 (Selby 2006), a correction for number of surveyors (one or two) was not made, since the methods did not indicate whether a correction was needed. Furthermore, at this site, many surveys occurred during late June to mid-July in 2003-2004 (seven each year), but peak count was used instead of median. For Prairie Coteau in 2000 (Schlicht 2001), a correction for $N=$ two surveyors was also not performed. If number of surveyors and use of peak rather than median counts from multiple survey dates in these recent years cause a bias, it would be against a negative trend as also done by Franzén and Johannesson (2007) and Groenendijk and van der Meulen 2004: (comparison of pre-1990 to 1990-2000 data). A calibration constant $>2$ for Swengel indices would be expected a priori to bias against declines since Swengel surveys weight earlier in the time series. The use of ranking (non-parametric) statistics here also accounts for the indices being relative abundance estimates, not precise population counts.

As a comparison (outgroup) to specialist butterflies, the same methods for identifying annual abundance indices were used for the five most frequently recorded non-specialist ("common") species in the combined database during the late June to mid-July period: Aphrodite fritillary, meadow fritillary, common wood-nymph, monarch, long dash. If it was unclear whether a sampling period was adequately in a species' main flight period or not (i.e., low recorded numbers could be due to timing or low fluctuation in abundance), for specialists the decision was biased against a negative trend but for common species, against a positive trend (Appendix 1). Swengel surveys in midAugust were used for a peak index in lieu of the same team's early July period in the same year only for univoltine species peaking between those two survey periods (regal fritillary, Aphrodite fritillary, common woodnymph); surveys in later years by other teams included dates in the mid/late July peak. Indices per hour were used unless indices per $\mathrm{km}$ increased number of years in the species' time series.

Trend (correlation of indices with year) was calculated for each species individually by site. The correlation coefficients $(r)$ (both as absolute value and with sign) were correlated with start year of the trend test, end year, $N$ years in the time series, and span of years (duration between start year and end year). These year variables were tested for a significant difference between specialist and common species. Sets of correlation coefficients have frequently been analyzed for patterns of spatial variation (e.g., SR Swengel and AB Swengel 2005b), often with unequal samples generating these coefficients (e.g., Hanski and Woiwod 1993; Williams and Liebhold 2000; Koenig 2006). The application here is to analyze coefficients for patterns of temporal variation. Since all analyzed indices represent relative abundance, no direct comparisons of abundance were made among species. Instead, only relative change within a site (as represented by correlation coefficients) was compared among species.

Two a posteriori sensitivity tests were performed to determine how much the adjustments of indices to make them comparable among teams influenced trend results. First, trends were re-calculated two ways: excluding Dana (1991) and Dana in litt. (5 March 1993), as this study was most different in methods (MRR) from the other studies (transect surveys) in this meta-analysis, and including only Dana (1991: Figs. 13-14) and not Dana in litt. (5 March 1993) by using the median published MRR capture rates (for Dakota and Ottoe Skippers only) as indices. Second, 
trends were re-calculated using other calibration constants: 2.42 for all Swengel indices (which affected only one site, the indices per $\mathrm{km}$ at Prairie Coteau) because the Schlicht and Swengel teams averaged a similar walking speed (Table 5), and 2.0 for all Swengel indices because this would be a logical value to account for the difference in number of observers in the absence of the validation analysis. The trends were also re-run with no adjustments for effort, by using no calibration constant for Swengel indices, the unadjusted indices reported by Dana in litt. (5 March 1993) for all four species for each of the three years in his study (as the mean of the range provided), and the peak date for all indices (not median date for Selby and Glenn-Lewin 1989, 1990). In each re-run of the trends, Schlicht and Swengel indices were re-compared to each other to identify which was the peak index for a species at each site each year.

\section{Results}

\section{Validation}

For the 18 species analyzed in the site-scale correlations, abundance indices significantly covaried between the two teams for $11(61 \%)$ species, including 2/3 specialists; no species significantly correlated negatively; and 17/18 species had positive correlations (Table 2). For the ten species analyzed in the subsite-scale correlations, two (20\%) significantly covaried in abundance indices (both per hour and per $\mathrm{km}$ ) between the two teams, no species significantly correlated negatively, and 9/10 species had positive correlations (Table 3). Indices could be calculated both per hour and per $\mathrm{km}$ for 12 pairs of site surveys (Table 4). For both types of indices, 10/12 species had positive correlations and 6-7 had significant correlations, all positive. The correlation coefficients per hour and per km (Tables 3 and 4) significantly covaried, as did the two kinds of indices to each other $(P<0.001$ for all these tests). The preponderance of positive correlations was significant in all sets of correlations in Tables $2(P<0.001), 3(P<0.02)$, and 4 $(P<0.05)$. In all survey datasets, survey time and survey distance covaried strongly (Table 5).

Correlation coefficients between teams correlated positively with total individuals observed and negatively with percent zero indices (non-significantly at the site scale and significantly at the subsite scale) and correlated negatively with percent mismatched zero indices (significantly at the site scale and non-significantly at the subsite scale) (Table 6). Total individuals and percent zero indices significantly and negatively correlated $(P<0.01$, tested separately for values in Tables 2, 3 and 4), but neither related significantly to percent mismatched zero indices $(P>0.10)$. Species included in "Trend" (below) that had such small samples in the dataset for this validation analysis as not to covary significantly (regal fritillary) or be unanalyzable (Ottoe and Arogos skippers) here had larger samples available in the surveys analyzed for trend.

\section{Calibration}

The calibration-constant between Swengel indices (two surveyors; unlimited-width transect) to Schlicht indices (one surveyor; fixed-width transect) varied, but Swengel
Table 3 Spearman rank correlations of Schlicht and Swengel population indices (individuals $/ \mathrm{h}$ ) of ten most recorded species $(*=$ prairie specialist $)$ in 25 visits to the same subsites $(N=15$ different subsites) in the same sites $(N=5$ different sites $)$ surveyed in the same years (1995-96) in midsummer (1-13 July)

\begin{tabular}{|c|c|c|c|c|c|c|c|}
\hline \multirow[t]{2}{*}{ Species } & \multirow[t]{2}{*}{$N$ individuals $^{\mathrm{a}}$} & \multirow{2}{*}{$\begin{array}{l}\text { Percent zero } \\
\text { Indices }^{\mathrm{b}}\end{array}$} & \multirow{2}{*}{$\begin{array}{l}\text { Percent mismatched } \\
\text { Zero indices }^{\mathrm{c}}\end{array}$} & \multicolumn{2}{|c|}{ Indices per hour } & \multicolumn{2}{|c|}{ Indices per $\mathrm{km}$} \\
\hline & & & & $r$ & $P$ & $r$ & $P$ \\
\hline Common ringlet & 16 & 78.0 & 44.0 & -0.160 & $>0.10$ & -0.160 & $>0.10$ \\
\hline Regal fritillary* & 20 & 72.0 & 40.0 & +0.124 & $>0.10$ & +0.124 & $>0.10$ \\
\hline Melissa blue & 17 & 86.0 & 20.0 & +0.159 & $>0.10$ & +0.159 & $>0.10$ \\
\hline Delaware skipper & 18 & 88.0 & 16.0 & +0.210 & $>0.10$ & +0.210 & $>0.10$ \\
\hline Monarch & 19 & 80.0 & 24.0 & +0.320 & $>0.10$ & +0.320 & $>0.10$ \\
\hline Long dash & 55 & 60.0 & 40.0 & +0.329 & $>0.10$ & +0.344 & $>0.10$ \\
\hline Clouded sulphur & 35 & 62.0 & 36.0 & +0.361 & $<0.10$ & +0.191 & $>0.10$ \\
\hline Dakota skipper* & 105 & 56.0 & 32.0 & +0.372 & $<0.10$ & +0.358 & $<0.10$ \\
\hline Poweshiek skipperling* & 350 & 40.0 & 40.0 & +0.459 & $<0.05$ & +0.428 & $<0.05$ \\
\hline Common wood-nymph & 840 & 36.0 & 16.0 & +0.887 & $<0.01$ & +0.854 & $<0.01$ \\
\hline
\end{tabular}


Table 4 Spearman rank correlations of Schlicht and Swengel population indices (per hour and per km) of 12 most recorded species $(*=$ prairie specialist) in 12 pairs of visits to the same sites ( $N=7$ different sites) surveyed in the same years (1995-1996) in midsummer (1-13 July)

\begin{tabular}{|c|c|c|c|c|c|c|c|}
\hline \multirow[t]{2}{*}{ Species } & \multirow[t]{2}{*}{$N$ individuals $^{\mathrm{a}}$} & \multirow{2}{*}{$\begin{array}{l}\text { Percent zero } \\
\text { Indices }^{\mathrm{b}}\end{array}$} & \multirow{2}{*}{$\begin{array}{l}\text { Percent mismatched } \\
\text { Zero indices }\end{array}$} & \multicolumn{2}{|c|}{ Indices per hour } & \multicolumn{2}{|c|}{ Indices per $\mathrm{km}$} \\
\hline & & & & $r$ & $P$ & $r$ & $P$ \\
\hline Regal Fritillary* & 36 & 54.2 & 58.3 & -0.201 & $>0.10$ & -0.107 & $>0.10$ \\
\hline Pearl crescent & 54 & 70.8 & 41.7 & -0.147 & $>0.10$ & -0.147 & $>0.10$ \\
\hline Northern brown & 51 & 75.0 & 33.3 & +0.181 & $>0.10$ & +0.181 & $>0.10$ \\
\hline Common ringlet & 26 & 66.7 & 33.3 & +0.287 & $>0.10$ & +0.338 & $>0.10$ \\
\hline Delaware skipper & 17 & 79.2 & 25.0 & +0.296 & $>0.10$ & +0.296 & $>0.10$ \\
\hline Long dash & 89 & 45.8 & 41.7 & +0.608 & $<0.05$ & +0.565 & $<0.10$ \\
\hline Melissa blue & 18 & 75.0 & 16.7 & +0.608 & $<0.05$ & +0.608 & $<0.05$ \\
\hline Dakota skipper* & 318 & 29.2 & 8.3 & +0.652 & $<0.05$ & +0.595 & $<0.05$ \\
\hline Monarch & 25 & 79.2 & 8.3 & +0.684 & $<0.05$ & +0.684 & $<0.05$ \\
\hline Common wood-nymph & 1316 & 4.2 & 8.3 & +0.685 & $<0.05$ & +0.748 & $<0.01$ \\
\hline Clouded sulphur & 78 & 12.5 & 8.3 & +0.788 & $<0.01$ & +0.816 & $<0.01$ \\
\hline Poweshiek skipperling* & 418 & 45.8 & 8.3 & +0.886 & $<0.01$ & +0.917 & $<0.01$ \\
\hline
\end{tabular}

a Total individuals recorded by both teams combined (all species with $>14$ individuals included)

b Total number of zero indices, combined for both teams, as a percent of total indices analyzed (two times $N$ site-pairs $=24$ )

c Total number of site-pairs where one team found 0 but other team found $>0$, as a percent

Table 5 Spearman rank correlation of distance $(\mathrm{km})$ versus time $(\mathrm{h})$ spent surveying

\begin{tabular}{llccc}
\hline Team & Date span & $N$ surveys & $r$ & $P$ \\
\hline Schlicht & 24 June-18 July, 23 Aug 1993-1997 & $201^{\mathrm{a}}$ & +0.680 & $<0.0005$ \\
Swengel & 18 June-20 Aug 1988-1997 & $769^{\mathrm{b}}$ & +0.875 & $<0.0005$ \\
Selby & 28 June-30 July 2003-2005 & $62^{\mathrm{c}}$ & +0.763 & $<0.0005$ \\
\hline
\end{tabular}

a $241.33 \mathrm{~h}$ on 356 transect surveys; distance was also calculated on 201 surveys, totaling $163.55 \mathrm{~km}$ in $93.85 \mathrm{~h}$

b $409.00 \mathrm{~km}$ and $235.79 \mathrm{~h}$

c $198.97 \mathrm{~km}$ and $176.567 \mathrm{~h}$

Table 6 Spearman rank correlations ( $r$ ) of coefficients in Tables 2-4 with $N$ individuals recorded by both teams combined, percent zero indices, and percent mismatched zero indices

\begin{tabular}{|c|c|c|c|c|c|c|}
\hline & \multicolumn{2}{|c|}{$N$ individuals $^{\mathrm{a}}$} & \multicolumn{2}{|c|}{ Percent zero ${ }^{b}$} & \multicolumn{2}{|c|}{ Percent mismatched zero ${ }^{c}$} \\
\hline & $r$ & $P$ & $r$ & $P$ & $r$ & $P$ \\
\hline \multicolumn{7}{|l|}{ Site scale (Table 2) } \\
\hline Indices per hour & +0.333 & $>0.10$ & -0.362 & $>0.10$ & -0.719 & $<0.01$ \\
\hline \multicolumn{7}{|c|}{ Subsite scale (Table 3 ) } \\
\hline Indices per hour & +0.915 & $<0.01$ & -0.794 & $<0.01$ & -0.302 & $>0.10$ \\
\hline Indices per $\mathrm{km}$ & +0.867 & $<0.01$ & -0.709 & $<0.05$ & -0.357 & $>0.10$ \\
\hline \multicolumn{7}{|l|}{ Site scale (Table 4) } \\
\hline Indices per hour & +0.462 & $>0.10$ & -0.450 & $>0.10$ & -0.906 & $<0.01$ \\
\hline Indices per $\mathrm{km}$ & +0.413 & $>0.10$ & -0.450 & $>0.10$ & -0.863 & $<0.01$ \\
\hline
\end{tabular}

a Total individuals recorded by both teams combined

b Total number of zero indices, combined for both teams, as a percent of total indices analyzed (two times $N$ site-pairs)

c Total number of site-pairs where one team found 0 but other team found $>0$, as a percent

indices were usually $>2$ times the Schlicht indices (Table 7). For the largest scale and largest sample (from Table 2), Swengel indices averaged 2.42 times the Schlicht indices (the calibration constant used in "Monitoring" below). In the smaller samples available for indices per $\mathrm{km}$, the calibration constant at the site scale (2.89) was used in 
Table 7 Grand mean of mean indices per species and calibration constant between Schlicht and Swengel grand means, and mean correlation coefficients $(r)$ from Tables $2-4$, for all, three specialist (regal fritillary, Poweshiek skipperling, Dakota skipper), and three widespread (clouded sulphur, common wood-nymph, monarch) species

\begin{tabular}{|c|c|c|c|c|c|}
\hline & Index type & Schlicht index & Swengel index & Calibration constant & Mean $r$ \\
\hline \multicolumn{6}{|l|}{ Site (Table 2) } \\
\hline All species $(N=18)$ & Per hour & 2.83 & 6.85 & 2.42 & +0.440 \\
\hline Specialists $(N=3)$ & Per hour & 4.11 & 9.22 & 2.24 & +0.537 \\
\hline Widespread $(N=3)$ & Per hour & 10.76 & 23.03 & 2.14 & +0.706 \\
\hline \multicolumn{6}{|l|}{ Subsite (Table 3) } \\
\hline \multirow[t]{2}{*}{ All species $(N=10)$} & Per hour & 4.43 & 10.87 & 2.45 & +0.306 \\
\hline & Per km & 2.26 & 5.50 & 2.43 & +0.283 \\
\hline \multirow[t]{2}{*}{ Specialists $(N=3)$} & Per hour & 5.91 & 8.92 & 1.51 & +0.318 \\
\hline & Per km & 3.73 & 5.44 & 1.46 & +0.303 \\
\hline \multirow[t]{2}{*}{ Widespread $(N=3)$} & Per hour & 7.68 & 24.51 & 3.19 & +0.522 \\
\hline & Per km & 2.89 & 11.48 & 3.97 & +0.455 \\
\hline \multicolumn{6}{|l|}{ Site (same $N$ : Table 4) } \\
\hline \multirow[t]{2}{*}{ All species $(N=12)$} & Per hour & 3.93 & 11.35 & 2.89 & +0.444 \\
\hline & Per km & 2.09 & 6.03 & 2.89 & +0.458 \\
\hline \multirow[t]{2}{*}{ Specialists $(N=3)$} & Per hour & 4.54 & 10.14 & 2.23 & +0.446 \\
\hline & Per km & 2.92 & 5.52 & 1.89 & +0.468 \\
\hline \multirow[t]{2}{*}{ Widespread $(N=3)$} & Per hour & 10.14 & 32.29 & 3.18 & +0.719 \\
\hline & Per km & 4.86 & 17.05 & 3.51 & +0.750 \\
\hline
\end{tabular}

"Monitoring" below. It was inconsistent whether the specialists (targets) or widespread species had larger or smaller calibration constant between the two teams. Specialists always had a lower constant than comparable samples of all species.

Individual calibration-ratios at the species scale had no significant relationships to size, detectability, $N$ individuals observed, percent zero indices, and percent mismatched zero indices. These ratios did not differ significantly by encounterability when including all species, but did $(P<0.05)$ when excluding the three specialists, skewing toward lower ratios with greater encounterability. The correlation of the calibration-ratio to the combined code (detectability and encounterability) was far from significant for all species but was significant when excluding the three specialists $(r=+0.57, P<0.05, N=15$ species), with ratios decreasing with greater combined detectability plus encounterability. Although surveys occurred on dates close to each other, Schlicht surveys usually followed Swengel surveys and this difference in date between the two teams (median 10 July for Schlicht, 7 July for Swengels) was significant $(P<0.05)$. Eight species were classified as later in the brood, six as intermediate, and four as earlier. But the calibration-ratio did not significantly relate to phenological category, either in a correlation using the three categories, or a binary test of later vs. intermediate/earlier combined. See "Trend" below for effects of alternate calibrations.

\section{Monitoring}

At the monitoring sites (Table 8), for specialists, 25/30 trend tests were negative regardless of significance (Table 9). This skewing to negative coefficients was highly significant $(P<0.0005)$. One species (Arogos skipper) also had a significant skewing to negative trends $(P<0.05)$. In addition, Ottoe skipper had $3 / 3$ negative trends, a sample too small for a significant probability but 2/3 sites had significant declines. Regal fritillary had the lowest proportion of negative trends (4/7). By contrast, common species had 16 negative trends regardless of significance, 16 positive, and 3 exactly 0 -an essentially random distribution (Table 9). Five individual trend tests of common species were significant ( 2 negative, 3 positive). No individual common species had a significant skewing to negative or positive trends. For all species combined, one site had a significant skewing of individual species trends: Prairie Coteau $(9 / 10$ negative, $P<0.05)$. Sample size was inadequate to test this by specialist vs. common species.

Specialists had significantly more negative trend coefficients than common species (mean $r$ with sign $=-0.21$ for specialists vs. +0.035 for common species, $P<0.01$ ), but degree of significance regardless of sign ( $r$ as absolute value) did not significantly vary between specialist and common species. Start year significantly differed between specialist and common species (median 1988 for specialists 
Table 8 Minnesota prairies used in long-term trend analysis; all were preserves managed primarily with fire during this study. Sources: TNC (1988, 1994, 2008), Wendt (1984), Schlicht (2003), Selby (2006), MDNR (2008)

\begin{tabular}{|c|c|c|c|c|}
\hline Name & Size $(\text { ha })^{\mathrm{a}}$ & Owner $^{\mathrm{b}}$ & Year purchased & County: Coordinates \\
\hline \multicolumn{5}{|l|}{ Felton Prairie } \\
\hline Bicentennial & 65 & Clay County & Not applicable & Clay: $47.06,96.42$ \\
\hline Blazingstar & 65 & $\mathrm{TNC}$ & 1975 & Clay: $47.06,96.41$ \\
\hline Chippewa & $446^{\mathrm{c}}$ & TNC \& DNR & $1971^{\mathrm{d}}$ & Chippewa, Swift: $45.15,95.93$ \\
\hline Glacial Lakes State Park & $162^{\mathrm{e}}$ & DNR & 1963 & Pope: $45.54,95.17$ \\
\hline \multicolumn{5}{|l|}{ Hole-in-the-Mountain } \\
\hline Old & $89^{\mathrm{f}}$ & TNC & 1978 & Lincoln: 44.29, 96.31 \\
\hline New & 55 (109) & TNC & ca. 1990 & Lincoln: 44.31, 96.30 \\
\hline Prairie Coteau & 133 & DNR & 1986 & Pipestone: $44.12,96.15$ \\
\hline \multicolumn{5}{|c|}{$\begin{array}{l}\text { Prairie patch sizes are applicable for the period when surveys were done; grassland patch size surrounding sites was larger than prairie size and, } \\
\text { where known, follows prairie size in parentheses }\end{array}$} \\
\hline \multicolumn{5}{|c|}{${ }^{\mathrm{b}} \mathrm{DNR}=$ Minnesota Department of Natural Resources, $\mathrm{TNC}=$ The Nature Conservancy } \\
\hline \multicolumn{5}{|c|}{$\begin{array}{l}\text { c Includes only TNC portion; DNR owns a large prairie in adjoining Lac Qui Parle Wildlife Management Area; some surveyors included DNR } \\
\text { land in a "Chippewa Prairie" survey }\end{array}$} \\
\hline \multicolumn{5}{|c|}{${ }^{\mathrm{d}}$ That information available for TNC but not DNR property in these sources } \\
\hline \multicolumn{5}{|c|}{${ }^{\mathrm{e}}$ Entire park is 2,423 acres, but most is not prairie } \\
\hline \multicolumn{5}{|c|}{${ }^{\mathrm{f}}$ Excludes preserve area east of U.S. Highway 75} \\
\hline
\end{tabular}

Table 9 Summary of Spearman rank correlations of trend (year versus abundance index) for specialist and common species, with binomial probability for non-random skewing of signs of correlation coefficients

\begin{tabular}{|c|c|c|c|c|c|c|}
\hline & \multirow[t]{2}{*}{$N$ sites } & \multicolumn{2}{|c|}{$N$ negative trends } & \multicolumn{2}{|c|}{$N$ positive } & \multirow[t]{2}{*}{ Binomial probability } \\
\hline & & All & Significant & All & Significant & \\
\hline \multicolumn{7}{|l|}{ Specialist species } \\
\hline Arogos skipper & $6^{\mathrm{a}}$ & 6 & 1 & 0 & 0 & $<0.05$ \\
\hline Dakota skipper & 7 & 6 & 0 & 1 & 0 & $>0.10$ \\
\hline Ottoe skipper & $3^{\mathrm{b}}$ & 3 & 2 & 0 & 0 & $>0.10$ \\
\hline Poweshiek skipperling & 7 & 6 & 0 & 1 & 0 & $>0.10$ \\
\hline Regal fritillary & 7 & 4 & 0 & 3 & 0 & $>0.10$ \\
\hline Total & 30 & 25 & 3 & 5 & 0 & $<0.0005$ \\
\hline \multicolumn{7}{|l|}{ Common species } \\
\hline Aphrodite fritillary & 7 & 5 & 2 & 2 & 0 & $>0.10$ \\
\hline Meadow fritillary & 7 & 4 & 0 & 3 & 1 & $>0.10$ \\
\hline Common wood-nymph & 7 & $2^{\mathrm{c}}$ & 0 & $5^{\mathrm{c}}$ & 1 & $>0.10$ \\
\hline Monarch & 7 & 5 & 0 & 2 & 0 & $>0.10$ \\
\hline Long dash & 7 & $1.5^{\mathrm{d}}$ & 0 & $5.5^{\mathrm{d}}$ & 1 & $>0.10$ \\
\hline Total & 35 & 17.5 & 2 & 17.5 & 3 & $=1.0$ \\
\hline
\end{tabular}

${ }^{\text {a }}$ No records for Blazing Star Prairie in the survey datasets in this study

${ }^{b}$ In range only at Hole-in-the-Mountain Prairie (new and old) and Prairie Coteau

c 1 negative, $2=0.0,4$ positive

d 1 negative, $10.0,5$ positive

and 1990 for common species $)(P<0.005)$, but end year did not $(P>0.10)$. Furthermore, start year and end year did not significantly correlate with $r$ (either as absolute value or with sign, for the entire sample and separately for specialist and common species). $R$ (with sign or as absolute value) did not significantly differ by whether the end year was 2005 or an earlier year $(P>0.10)$, for all species and for specialists (not testable for common species as $N=5$ for end year $<2005$ ). Specialists did not have significantly more years in a trend test (mean 8.0 years) vs. common species (mean 7.3 years) (median $=7$ years for both groups) $(P>0.10)$. Number of years did not significantly 
correlate with $\mathrm{r}$ (with sign), while $r$ (as absolute value) did so negatively (as expected, because the critical value of $r$ at $P<0.05$ declines with increasing $N$ ) for all species ( $r=-0.25, P<0.05, N=65$ ) and for common species ( $r=-0.37, P<0.05, N=35$ ) but non-significantly for specialists $(r=-0.13, P>0.10, N=30)$. Span of years (duration between start year and end year) in a trend test did significantly correlate negatively with $r$ (with sign) for all species $(r=-0.29, P<0.05, N=65)$ but not for species subgroups (specialist or common species) and not with $r$ as absolute value. Span of years did not significantly differ between the specialist and common species.

For some specialists at some sites, thresholds were apparent between the last year when a higher index (or any individual) was recorded and all subsequent years, when consistently lower indices (or zeroes) were recorded (Table 10). While adjacent sites had similarly timed thresholds within species (Ottoe skipper at Hole-in-theMountain old and new; Poweshiek at Bicentennial and Blazing Star), these thresholds were not synchronized within species among sites in different counties (e.g., Arogos skipper at Glacial Lakes vs. Hole-in-the-Mountain new; Ottoe skipper at Hole-in-the-Mountain vs. Prairie Coteau; Poweshiek at Bicentennial and Blazing Star vs. Glacial Lakes). No positive thresholds were identified for specialists, while both positive and negative thresholds occurred for common species, although fewer distinct threshold patterns were apparent for the latter.

The other state-listed butterflies (Table 1) were not analyzed in this study. For Uhler's arctic and common branded skipper, a few surveys at several sites were in proper timing and range (Coffin and Pfannmuller 1988) but none were recorded. Garita skipperling and Uncas skipper were not known to occur in counties covered by these datasets (Coffin and Pfannmuller 1988). Leonard's skipper was recorded in August during 1989-1993 at a total of five sites, but sampling occurred in its flight period in too few years for trend analysis. Data on phlox and leadplant moths are in Swengel and Swengel (1999b).
Table 10 Threshold (boldfaced and italicized) at which a persistent change in index occurred, if the change persisted for at least three and all remaining indices: for declines, the last time a higher rate was seen (rates prior are not presented and could have been lower) and the first time all subsequent rates were less than a certain value; for increases, all values in the earlier period were at the lower rate, and all values in the later period were at the higher rate

\begin{tabular}{|c|c|c|c|c|c|c|c|c|c|c|c|c|c|c|c|c|c|c|c|}
\hline & 81 & 88 & 89 & 90 & 91 & 92 & 93 & 94 & 95 & 96 & 97 & 98 & 99 & 00 & 01 & 02 & 03 & 04 & 05 \\
\hline \multicolumn{20}{|l|}{ Specialists } \\
\hline \multicolumn{20}{|l|}{ Arogos skipper } \\
\hline Bicentennial & & & & & $>0$ & 0 & 0 & & 0 & 0 & & & & & & & & & 0 \\
\hline Glacial Lakes & & & & & & & & & & $>2$ & & & & & & & 0 & 0 & 0 \\
\hline Hole-new & & & & $>3$ & $<1$ & $<1$ & & $<1$ & 0 & $<1$ & & & & & & & & & 0 \\
\hline \multicolumn{20}{|l|}{ Dakota skipper } \\
\hline Chippewa & & & & & & & & & $>3$ & 0 & 0 & 0 & & & & & & & \\
\hline \multicolumn{20}{|l|}{ Ottoe skipper } \\
\hline Hole-new & & & & $>1$ & $<1$ & 0 & & 0 & 0 & 0 & & & & & & & & & 0 \\
\hline Hole-old & $>8$ & & $<3$ & 0 & 0 & $<1$ & & 0 & $<4$ & 0 & & & & & & & & & \\
\hline Prairie Coteau & & & & & & & & & $>0 k$ & 0 & & & & 0 & & & & & 0 \\
\hline \multicolumn{20}{|c|}{ Poweshiek skipperling } \\
\hline Bicentennial & & $>4$ & & & & $<1$ & 0 & & 0 & 0 & $<1$ & & & & & & & & \\
\hline Blazing Star & & $>14$ & & & & 0 & 0 & & $<3$ & 0 & 0 & & & & & & & & \\
\hline Glacial Lakes & & & & & & & & & & $>21$ & & & & & $<5 k$ & & $<1$ & $<1$ & 0 \\
\hline \multicolumn{20}{|l|}{ Regal fritillary } \\
\hline Glacial Lakes & & & & & & & & & & $0<1$ & & & & & & & $>10$ & $>13$ & $>2$ \\
\hline \multicolumn{20}{|l|}{ Common species } \\
\hline \multicolumn{20}{|l|}{ Aphrodite fritillary } \\
\hline Bicentennial & & & & & & & $>8$ & & 0 & 0 & & & & & & & & & 0 \\
\hline Blazing Star & & & & & & & $>1$ & & 0 & 0 & & & & & & & & & 0 \\
\hline \multicolumn{20}{|l|}{ Meadow fritillary } \\
\hline Glacial Lakes & & & & & & & & & & 0 & & & & & & & $>0$ & $>0$ & $>0$ \\
\hline
\end{tabular}

All years after the threshold are included. Indices are per hour unless followed by a $\mathrm{k}$ to signify per km, and are rounded to the nearest integer (if presented as $>0$, that is also $<1$; if presented as $<2$, that is also $>1$ ) 
The a posteriori sensitivity tests indicated minor effects on the overall outcome. Changing indices from Dana (1991) to only the median MRR capture rates resulted in a change from 4/4 negative correlations (one significant) for the four affected specialist skippers at Hole-in-the-Mountain (old) to $3 / 4$ negative (none significant), for an overall change to the entire meta-analysis from 25/30 negative trends for specialists to 24/30 (still significantly skewed negative, $P<0.0005$ ). Excluding Dana (1991) altogether resulted in 2/4 negative trends (none significant) and 23/30 negative trends overall (still significantly skewed negative, $P<0.005)$. Changing the calibration constant to 2.42 for all Swengel indices (affecting eight species at Prairie Coteau) resulted in no change in sign or significance of trend tests. The two largest changes in adjusting indices resulted in no change in overall outcome between specialist and common species, but with an increasingly negative shift in the coefficients. Changing the calibration constant to 2.0 resulted in no change in sign or significance of trends for specialists but the mean $r$ changed from -0.21 to -0.24 (a significant decrease, $P<0.005$ ), while common species shifted from an even distribution to 19 negative and 16 positive trends (still a non-significant distribution, $P>0.10$ ) and from a mean $r$ of +0.035 to +0.006 (a significant decrease, $P<0.005)$. Changing to no adjustments resulted for specialists in an increase in 1 negative and $10.0 r$ (reducing positive trends by 2) and a mean $r$ of -0.32 (a significant decrease, $P<0.001$ ), while common species shifted to 19 negative, 2 with $r=0.0$, and 14 positive trends (still non-significant, $P>0.10$ ), with a mean $r$ of -0.066 (a significant decrease, $P<0.001$ ).

\section{Discussion}

\section{Validation}

In spite of differences between the two teams' survey protocols, an overwhelming non-random pattern of covariance occurred in abundance indices between the Schlicht and Swengel teams when indices were matched by year and location (Tables 2, 3 and 4). The site-scale comparison could have greater statistical power (i.e., more frequent significant covariance) due to the greater survey effort used to obtain the indices. The strength of covariance statistically related either to number of individuals (positively) and percent zero indices (negatively), or to percent mismatched zero indices (negatively), suggesting that weaker correlations occurred for species outside their main flight period and/or localized in distribution within a site. The very strong correlation between survey time and distance within each team (Table 5) explain why indices per hour and per $\mathrm{km}$ produce consistent results (Tables 3 and 4).
When Thomas (1983) validated a single transect survey through core habitat of the butterfly species during the main flight period to MRR results, he concluded that an even more approximate survey method would rank the abundance of different populations adequately. Based on that finding, it is not surprising that the nonparametric ranked statistics used here (which are more conservative than parametric tests) nonetheless detected robust patterns.

In this analysis, transect surveys by different teams at the same sites but not the same routes within sites produced similar rankings of species abundance among sites. This suggests the validity of combining survey datasets from different teams for monitoring butterfly abundance in western Minnesota prairies. In spite of the sampling error inherent in individual $250 \mathrm{~m}$ transects analyzed by Pellet (2008), robustness of indices greatly increased in that study when more subsites were lumped together. Likewise, consistent (co-varying) patterns emerged in this study, which mostly had much longer than $250 \mathrm{~m}$ transect routes used for indices, especially at the site scale. The premise of this meta-analysis is that transect survey indices can be used for robust ranking not only of sites within year (per Thomas 1983) but within site among years.

This study also indicates that, in the absence of data from fixed transects sampled frequently per year for many years, an adequate dataset can result if survey effort (preferably both distance and time), location (site or subsite), date, number of surveyors, and number of individuals of as many species as possible are recorded. A considerable confounding factor is the dramatic variation in butterfly phenology by up to three or more weeks among years in the midwestern USA (Swengel and Swengel 1999c): e.g., peak Dakota skipper numbers occurred on 9-14 July in 1979 (Dana 1991) but 20-24 June in 1988 (Appendix 1, Selby and Glenn-Lewin 1989). Great care is required to obtain surveys during the main flight period (e.g., most teams used a multiple-week survey period and re-surveyed sites) and to eliminate surveys outside the main flight period (e.g., certain years of Swengel surveys not included for specific species per Appendix 1).

While a comprehensive monitoring program is preferable, as more species are more systematically covered, this appears impractical. The study region is about $96 \mathrm{~km}$ eastwest by $326 \mathrm{~km}$ north-south $\left(31,000 \mathrm{~km}^{2}\right)$. The city of record for each team in this meta-analysis was outside this area, from 115 to $513 \mathrm{~km}$ (median 256) straight-line distance away from the nearest site in Table 8 . The counties containing the study sites (Table 8 ) have $<10$ people per square $\mathrm{km}$ (1990 and 2000 censuses), compared to $>200$ in Great Britain during the same time period (WAEG 2002). The methods and species in this study are adequate to provide information on the effectiveness of prairie conservation and management. This approach might also be 
appropriate in other regions with both high habitat loss (cf. about 99\% in tallgrass prairie per Samson and Knopf 1994) and low human population density and therefore few qualified surveyors available.

\section{Calibration}

As a result of this validation, calibration constants between Schlicht (one surveyor; fixed-width transect) and Swengel (two surveyors; unlimited-width transect) indices were calculated (Table 7), both per hour (2.42) and per km (2.89). At the species level, the calibration ratio of Swengel to Schlicht indices appeared to increase (as expected) in relation to reduced encounterability, and a combination of reduced detectability and encounterability (both patterns significant when excluding the three specialists). Otherwise, patterns explaining species-specific variability in calibration ratios were difficult to identify. Dennis et al. (2006) obtained relatively more significant patterns related to higher (or sooner) butterfly numbers detected than in this study, in much larger datasets that involved more varied vegetation (i.e., canopy heights) but with some variation in which variables mattered and how among those datasets. Significant variables relevant to this study included wing length (although contradictorily), brightness, and long flight periods. While it was not possible to calculate a calibration constant to any other teams, it is suggestive that a systematic skewing did not occur with datasets from later years than sampled by Schlicht and Swengels, because end year of a trend test did not significantly relate to trend result (see "Monitoring"). See "Trend" below for discussion of alternate calibrations.

\section{Monitoring}

Specialists had significantly different outcomes from common species, with specialists strongly skewed to negative trends while common species had an equal number of positive and negative trends (Table 9). All significant trends (3/3) for specialists were negative, while only $2 / 5$ were negative for common species. While trends for individual species at individual sites have meaning, these would be more prone to sampling error (cf. Harker and Shreeve 2008) and confounding factors (e.g., comparability among teams, variation in weather and phenology on survey date) than the relative comparisons of outcome between specialist and common species, since the same methods were applied to all species and systematic differences in statistical power $(N$ years, span of years) did not occur between specialist and common species. Since end year did not significantly differ between specialist and common species, and end year did not significantly relate to trend results, annual climatic variation as well as calibration differences between Selby in
2005 vs. earlier teams do not explain the negative trends of specialists nor the difference in trends between specialist and common species. Thus, outcomes of the trend tests were not attributable to differential statistical power between specialist and common species, or a climatic pattern in a certain year, or systematic miscalibration between earlier and later teams, but rather whether the species was a specialist or not.

The general pattern of specialist decline reported here is confirmed in presence/absence analysis by MDNR (2007a), cross-referenced to Coffin and Pfannmuller (1988), that extensive surveys indicated rapid disappearance of Dakota skipper from remnant habitat, very few records for Poweshiek skipperling during 2003-2006 (while it was formerly the most frequently encountered prairie obligate skipper), and no observations of Ottoe skipper reported in the state since 1995. Direct confirmation of the trend results for common species was not available, but true patterns in some species are likely. In Europe, widespread species show less decline than localized butterflies, or even stable and increasing patterns (Pollard and Eversham 1995; Kuussaari et al. 2007), with approximately as many increases as decreases among widespread species since 1980 (van Swaay et al. 2006). This resembles the equal number of local increases and declines in this study.

On the one hand, the sensitivity tests indicated that the adjustments of indices to make them more comparable to Schlicht indices performed as expected by successfully biasing against negative trends, since lower calibration constants and no adjustments produced coefficients significantly more negative than the a priori method used. On the other hand, all sets of trend tests (regardless of whether and how adjustments were done) produced the same overall outcome: specialists significantly skewed to negative trends, which had significantly lower coefficients than the approximately even distribution of positive and negative coefficients for common species. Different methods of including or excluding the most different study (Dana 1991 and Dana in litt. 5 March 1993) had a minor effect on the overall outcome, as this affected only four of ten species at one of seven sites. These results suggest the benefit of obtaining larger datasets, even at the expense of rigor and with the comparability issues inherent to meta-analyses.

Implications for conservation

Warren (1993) demonstrated that losses of rare/localized butterflies had been just as great on protected as on unprotected land. Our study confirms a similar situation of prairie butterfly decline in prairie reserves in the highly altered and fragmented landscape of western Minnesota. In contrast to the "semi-natural" communities described by 
Warren (1993), these sites in Minnesota (Table 8) contain high-quality ("virgin" - i.e., never tilled) native vegetation explicitly managed throughout this study for natural ecosystem value primarily with fire, usually on a rotation of about 3-6 years (see citations in Table 8). They are relatively large and longer preserved, and include those sites considered most valuable for prairie butterfly conservation (Dana 1997). As in Warren's (1993) and van Swaay et al.'s (2006) studies, multiple and differing causes of decline (not just burning) can be involved in the Minnesota prairie landscape, both among reserves and between reserves and the non-conserved landscape.

A direct comparison of burning to alternative managements was not possible in this study due to the lack of time series of indices at sites not managed with fire. Burning usually began in a reserve before much butterfly surveying had occurred, most reserves were managed primarily with fire, and most surveys focused on sites after they were conserved (Wendt 1984; TNC 1988, 1994; Swengel 1996, 2001; Swengel and Swengel 1997; Schlicht 2001, 2003; Nekola 2002). However, the pronounced declines of specialist but not common butterflies in this study is consistent with research that fire management is most unfavorable for specialist butterflies, compared to other butterfly species in prairies, and that other unintensive management types tend to be more favorable for specialist butterflies (Swengel 1998, 2001; Schlicht 2001, 2003; Swengel and Swengel 2007).

Are better outcomes possible for prairie-specialist butterflies? In the USA as well as other countries, favorable results (stable or increasing trends) have occurred for localized butterflies of open vegetation in highly fragmented landscapes when management was designed specifically in consideration of individual butterfly species' biology and requirements, not generally for a vegetative or ecosystem type (Thomas 1984; New 1993; Pollard and Yates 1993; New et al. 1995; Oates 1995; Robertson et al. 1995; Thomas 1995; Pullin 1996; Mattoni et al. 2001; Pryke and Samways 2001; Bourn and Thomas 2004; Sands and New 2002; Swengel and Swengel 2005a, 2007). Because many midwestern prairies were managed for many years with light grazing or haying until being made into preserves, and unintensive regimes of grazing, haying, mowing, localized brush-cutting, and idling tend to support higher populations of prairie-specialist butterflies than burning, these methods should be more extensively studied and employed in prairie conservation (McCabe 1981; Swengel 1996, 1998, 2001; Swengel and Swengel 1999a; Schlicht 2001, 2003; Powell et al. 2007; Schlicht et al. 2007). As a result, ongoing research in western Minnesota on grazing management as it affects prairie-specialist species (Selby 2006) is very valuable.

As found elsewhere (Maes et al. 2006; Dennis et al. 2007), matrix (non-habitat) for one butterfly species is habitat for others, but the boundaries between matrix and habitat may not be discrete. That is, a species may use some resources in the adjoining matrix off the prairie preserve (Dana 1991). Conversely, not all of a prairie reserve, not even all the high-quality prairie vegetation in a reserve, may be habitat for a prairie-specialist butterfly species (McCabe 1981; Dana 1991, Schlicht et al. 2007). Furthermore, presence of both upland and lowland grassland in a site associates with significantly higher abundance for Poweshiek skipperling, Dakota skipper, and regal fritillary even though these species significantly peak in abundance in dry prairie grassland (Swengel 1997; Swengel and Swengel 1999a). While "core areas" (areas of highest abundance) in dry prairie are useful focuses for favorable management (e.g., Swengel and Swengel 2007), it would be more beneficial to manage favorably all components required by the butterfly (e.g., lowlands as well as uplands). As reported elsewhere for other butterflies (Maes et al. 2006; Dennis et al. 2007), for most favorable outcomes, the specific resources and management tolerances required by prairie specialists need to be identified (e.g., McCabe 1981; Swengel 1997; Schlicht and Orwig 1998; Swengel and Swengel 1999a; Schlicht 2001) and incorporated into individual site management plans.

The results here also indicate a contrasting outcome for butterflies between an ecosystem (or vegetative) approach to reserve selection vs. management after preservation. Other studies have validated that using plant species richness or vegetative diversity for reserve selection is effective at capturing populations of associated specialist butterflies and other insects (Panzer and Schwartz 1998; Haddad et al. 2001; Kerr et al. 2001; Shuey 2005). Prairie species of conservation concern are also effectively captured by strategic use of an umbrella species, like the greater prairie-chicken (Tympanuchus cupido pinnatus), which may outperform a strategy of locating the largest prairie patches (Poiani et al. 2001). However, butterfly conservation outcomes in midwestern USA prairies and savannahs managed for ecosystem value primarily through restoring ecological processes (especially fire) have often been poor for specialized butterflies, but significantly better when alternative managements have been employed, especially by applying findings from prior research into management responses of individual species (McCabe 1981; Schlicht and Orwig 1998; Schlicht 2001; Swengel 2001; Swengel and Swengel 2001a, 2007; Powell et al. 2007; Schlicht et al. 2007). For the Karner blue, much better long-term trends occurred on reserves using management modified to help this federally endangered butterfly (e.g., permanent non-fire refugia) than in the landscape at large (including public lands) (Swengel and Swengel 2005a, 2007) or in other states where ecosystem 
management with fire was the principle management (Grigore and Windus 1994; Lane and Dana 1994). Other invertebrates such as grassland snails (Nekola 2002) and other grassland insects of conservation concern besides butterflies (Swengel 2001) have also fared significantly better with alternatives to fire.

Thomas et al. (2004) found that butterflies declined sooner and steeper than birds and plants. Thus, declines of butterflies (the best studied of those organisms with characteristics that predispose greater vulnerability, such as low dispersal tendency and short, often synchronized generations; cf. review in Bobo et al. 2006) are a warning of possible declines of other less studied groups while altering management to be more favorable for butterflies may improve the outcome for other groups, and therefore for the ecosystem.

Even with the vast destruction of prairie (Samson and Knopf 1994), relatively many populations of prairiespecialist butterflies have been documented in western Minnesota prairies in extensive surveys (Coffin and Pfannmuller 1988; the datasets used here). Unfortunately, preserving vegetation and inventorying reserves are not sufficient to safeguard against systematic declines in prairie-specialist butterflies. As Shuey (2005) noted, butterfly species will likely continue to decline unless reserves are designed and managed specifically with consideration for these species.

Acknowledgements The Schlicht surveys were funded by Minnesota's Nongame Wildlife Tax Checkoff (through MNDR's Natural Heritage and Nongame Research Program), USFWS's Partnerships for Wildlife Program, Minnesota Chapter of The Nature Conservancy, USFWS Endangered Species Program. Richard Baker (MDNR) administered the project, and also assisting were Robert Dana (MDNR), David Cuthrell (NDSU), Ed Brekke-Kramer (MDNR), Brian Winter (TNC), staff at Blue Mounds State Park, and Jim Messina (editing). Mike Saunders (1993-94), Timothy Orwig (1997), John Fleckenstein (1993), John Schladweiler (1994), and Frank Olsen (2000) participated in surveys for the Schlicht team. The Swengel surveys were funded in part by the Minnesota Chapter of The Nature Conservancy (1990-91) and Drs William and Elsa Boyce (1992-97). We are very grateful to the many lepidopterists who have surveyed Minnesota's prairie butterflies and shared their observations with us, and to the agencies that have supported their surveys and posted them on the Internet. We thank two anonymous reviewers for numerous helpful comments.

Open Access This article is distributed under the terms of the Creative Commons Attribution Noncommercial License which permits any noncommercial use, distribution, and reproduction in any medium, provided the original author(s) and source are credited.

\section{Appendix 1}

Range of survey dates (MDD) (Month-day) for indices at long-term monitoring sites and total individuals observed (in parentheses) at all survey sites by that team in that span of dates, by team and year; does not include Dana 19791981 and Selby 1988-1990 (since the median rate from a range of survey dates was used) and 1980 indices derived from Dana in litt. (5 Mar 1993). See Methods for sources of datasets.

\section{Specialist species}

Arogos skipper

Schlicht: 1993: 711-718 (0); 1994: 706 (4); 1995: 711712 (14); 1996: 710-715 (10); 2000: 713 (2)

Selby: 2003: 717 (0); 2004: 719 (0); 2005: 712-715 (30)

Swengels: 1990: 716-719 (37); 1991: 708-711 (18);

1992: 706-711 (10); 1994: 704-705 (7)

\section{Dakota skipper}

Britten: 1998: 708-709 (0: species found in Minnesota on 702-716)

Schlicht: 1993: 711-718 (26); 1994: 706 (5); 1995: 701 (14: higher index than at same site on 707 and 711),706713 (101); 1996: 701 (11: higher index than on 706 and 711 at same site),707-710 (131)

Selby: 2003: 628 (10); 2004: 713 (8); 2005: 701-703 (96) and 709 (11)

Swengels: 1988: 620-622 (52); 1989: 630 (12); 1992:

706-710 (67); 1993: 705-709 (188); 1994: 704-705

(24); 1996: 708 (35); 1997: 707-710 (48)

\section{Ottoe skipper}

Schlicht: 1995: 710-711 (6); 1996:714-715 (0); 2000:

$713(0)$

Selby: 2005: $713(0)$

Swengels: 1989: 630 (13); 1990: 716 (12); 1991: 708 (1);

1992: 706-707 (1); 1994: 704-705 (0)

Poweshiek skipperling

Schlicht: 1993: 711-718 (143); 1994: 706 (5); 1995: 707-713 (381); 1996: 630 (11: higher index than on 701, 706, and 711 at same site),704 (38: higher index than on 709 and 714 at same site), 707-715 (334)

Selby: 2003: 706 (1); 2004: 713 (0); 2005: 701-706 (30)

Swengels: 1988: 620-622 (306); 1989: 630 (254); 1992: 706-710 (559); 1993: 705-709 (47); 1994: 704-705 (701); 1995: 706 (11); 1997: 707-710 (67) 
Regal fritillary

Mason: 1998: 721 (129); 1999: 727,810 (91,157)

Schlicht: 1993: 711 (3); 1994: 706 (1); 1995: 707-713 (57); 1996: 711-715 (38)

Selby: 2003: 718 (28); 2004: 721 (72); 2005: 703 (41) and 712-715 (318)

Swengels: 1988: 620-622 (67); 1989: 630 (44); 1990: 716-719 (672); 1991: 708-711 (861); 1992: 706 (53: indices higher than at sites during 817-819), 817-819 (446); 1993: 816-818 (465: indices higher than at sites during 705-709); 1994: 704-705 (304); 1996: 711 (14)

\section{Common species}

\section{Aphrodite fritillary}

Schlicht: 1993: 711 (3); 1994: 706 (0); 1995: 706-713 (32); 1996: 711-715 (17)

Selby: 2003: 718 (0); 2004: 722 (8); 2005: 701-703 (10) and 711-715 (24)

Swengels: 1989: 630 (27); 1990: 716-719 (228); 1991: $708-711$ (278) and 808 (65); 1992: 706 (12) and 817819 (88); 1993: 816-818 (207); 1994: 704-705 (156)

\section{Common wood-nymph}

Schlicht: 1993: 717-718 (267); 1994: 706 (110); 1995: 709-713 (534); 1996: 711-715 (404)

Selby: 2003: 708 (153) and 717 (111); 2004: 715-719 (529); 2005: 703 (252) and 706 (431) +and 712-715 (1083)

Swengels: 1990: 716-719 (2000); 1991: 708-711 (3222); 1992: 707 (286) and 817-819 (806); 1993: 816-818 (1117); 1994: 704-705 (1249); 1996: 709 (232)

Long dash

Schlicht: 1994: 706 (0); 1995: 702-709 (25); 1996: 701705 (102)

Selby: 2003: 701 (2); 2004: 713 (2); 2005: 626-706 (9) Swengels: 1988: 620-622 (28); 1989: 630 (25); 1992: 706-710 (35); 1993: 705-708 (43); 1994: 704-705 (50); 1995: 702-706 (64); 1996: 711 (7); 1997: 707-710 (21)

Meadow fritillary

Schlicht: 1993: 711-718 (8); 1994: 706 (0); 1995: 709713 (28); 1996: 704-714 (13)

Selby: 2003: 718 (1); 2004: 717 (1); 2005: $701-703$ (68) and $711-715$ (43)
Swengels: 1990: 716-719 (74); 1991: 708-711 (284); 1992: 706-711 (237); 1993: 705-709 (6); 1994: 704705 (271); 1996: 711 (2); 1997: 707-710 (2; 65 in adjacent southeastern North Dakota)

\section{Monarch}

Schlicht: 1993: 711 (4); 1994: 706 (1); 1995: 706-713 (4); 1996: 711-715 (24)

Selby: 2003: 708 (8); 2004: 715 (0); 2005: 711-715 (97) Swengels: 1991: 708-711 (221); 1992: 706-711 (166); 1993: 705-708 (13); 1994: 704-705 (58); 1997: 707$710(27)$

\section{References}

Bobo KS, Waltert M, Fermon H et al (2006) From forest to farmland: butterfly diversity and habitat associations along a gradient of forest conversion in southwestern Cameroon. J Insect Conserv 10:29-42. doi:10.1007/s10841-005-8564-x

Bourn NAD, Thomas JA (2004) The challenge of conserving grassland insects at the margins of their range in Europe. Biol Conserv 104:285-292. doi:10.1016/S0006-3207(01)00193-8

Britten H (2001) Conservation genetics of the Dakota Skipper (Hesperia dacotae). Report to the Minnesota Department of Natural Resources, St. Paul. http://files.dnr.state.mn.us/eco/nongame/ projects/consgrant_reports/2001/2001_britten.pdf. Accessed 5 Feb 2008

Britten HB, Glasford JW (2002) Genetic population structure of the Dakota skipper (Lepidoptera: Hesperia dacotae): a North American prairie obligate. Conserv Genet 3:363-374. doi: 10.1023/A:1020576732699

Coffin B, Pfannmuller L (eds) (1988) Minnesota's endangered flora and fauna. University of Minnesota Press, St. Paul

Dana RP (1991) Conservation management of the prairie skippers Hesperia dacotae and Hesperia ottoe: basic biology and threat of mortality during prescribed burning in spring. Minnesota Agric Exp Sta Bull 594:1-63

Dana R (1997) Characterization of three Dakota skipper sites in Minnesota. Report to the U.S. Fish and Wildlife Service by the Minnesota Department of Natural Resources, St. Paul. http:// files.dnr.state.mn.us/eco/nongame/projects/consgrant_reports/ 1997/1997_dana.pdf. Accessed 5 Feb 2008

Dennis RLH (1993) Butterflies and climate change. Manchester University Press, Manchester

Dennis RLH, Thomas CD (2000) Bias in butterfly distribution maps: the influence of hot spots and recorder's home range. J Insect Conserv 4:73-77. doi:10.1023/A:1009690919835

Dennis RLH, Sparks TH, Hardy PB (1999) Bias in butterfly distribution maps: the effects of sampling effort. J Insect Conserv 3:33-42. doi:10.1023/A:1009678422145

Dennis RLH, Shreeve TG, Isaac NJB et al (2006) The effects of visual apparency on bias in butterfly recording and monitoring. Biol Conserv 128:486-492. doi:10.1016/j.biocon.2005.10.015

Dennis RLH, Shreeve TG, Sheppard DA (2007) Species conservation and landscape management: a habitat perspective. In: Stewart AJA, New TR, Lewis OT (eds) Insect conservation biology: the 22nd symposium of the Royal Entomological Society. Royal Entomological Society, St. Albans, UK, pp 92-126 
Franzén M, Johannesson M (2007) Predicting extinction risk of butterflies and moths (Macrolepidoptera) from distribution patterns and species characteristics. J Insect Conserv 11:367390. doi:10.1007/s10841-006-9053-6

Grigore MT, Windus JL (1994) Decline of the Karner blue butterfly in the oak openings of northwest Ohio. In: Andow DA, Baker RJ, Lane CP (eds) Karner blue butterfly: a symbol of a vanishing landscape. Minnesota Agric Expt Sta Misc Publ 84-1994, St. Paul, pp 135-142

Groenendijk D, van der Meulen J (2004) Conservation of moths in the Netherlands: populations, trends, distribution patterns, and monitoring of day-flying moths. J Insect Conserv 8:105-118

Haddad NM, Knops JMH, Tilman D et al (2001) Contrasting effects of plant richness and composition on insect communities. Am Nat 158:17-35. doi:10.1086/320866

Hanski I, Woiwod IP (1993) Spatial synchrony in the dynamics of moth and aphid populations. J Anim Ecol 62:656-668. doi: $10.2307 / 5386$

Harker RJ, Shreeve TG (2008) How accurate are single site transect data for monitoring butterfly trends? Spatial and temporal issues identified in monitoring Lasiommata megera. J Insect Conserv 12:125-133. doi:10.1007/s10841-007-9068-7

Kerr JT, Southwood TRE, Cihlar J (2001) Remotely sensed habitat diversity predicts butterfly species richness and community similarity in Canada. Proc Natl Acad Sci USA 98:11365-11370. doi:10.1073/pnas.201398398

Koenig W (2006) Spatial synchrony of monarch butterflies. Am Midl Nat 155:39-49. doi:10.1674/0003-0031(2006)155[0039:SSOMB] 2.0.CO; 2

Komonen A (2007) Are we conserving peripheral populations? An analysis of range structure of longhorn beetles (Coleoptera: Cerambycidae) in Finland. J Insect Conserv 11:281-285. doi: 10.1007/s10841-006-9043-8

Kuussaari J, Heliölä J, Pöyry J, Saarinen K (2007) Contrasting trends of butterfly species preferring semi-natural grasslands, field margins and forest edges in northern Europe. J Insect Conserv 11:351-366. doi:10.1007/s10841-006-9052-7

Lane CP, Dana R (1994) The status of the Karner blue butterfly in Minnesota. In: Andow DA, Baker RJ, Lane CP (eds) Karner blue butterfly: a symbol of a vanishing landscape. Minnesota Agric Expt Sta Misc Publ. 84-1994, St. Paul, pp 123-128

MacKenzie DI, Nichols JD, Sutton N et al (2005) Improving inferences in population studies of rare species that are detected imperfectly. Ecology 86:1101-1113. doi:10.1890/04-1060

Maes D, Shreeve TG, Dennis RLH et al (2006) Editorial: a special issue on insect habitats. J Insect Conserv 10:89-93. doi:10.1007/ s10841-006-6285-4

Marrone GM (2002) Field guide to butterflies of South Dakota. South Dakota Department of Game, Fish and Parks, Pierre

Mason KR (2001) Comparison of prairie sites and classification of their habitat attributes in relation to abundance of the regal fritillary butterfly (Speyeria idalia). Report to the Minnesota Department of Natural Resources, St. Paul. http://files.dnr.state. mn.us/eco/nongame/projects/consgrant_reports/2001/2001_mason. pdf

Mattoni R, Longcore T, Zonneveld C, Novotny V (2001) Analysis of transect counts to monitor population size in endangered insects: the case of the El Segundo blue butterfly (Euphilotes bernardino allyni). J Insect Conserv 5:197-206. doi:10.1023/A:101798 7929824

McCabe TL (1981) The Dakota skipper Hesperia dacotae (Skinner): range and biology, with special reference to North Dakota. J Lepid Soc 38:179-193

Minnesota Department of Natural Resources (2007a) Draft amendments to Minnesota's list of endangered, threatened, and special concern species-January 2, 2007. http://files.dnr.state.mn.us/input/ rules/ets/all.pdf. Minnesota Department of Natural Resources, St. Paul. Accessed 4 Jan 2008

Minnesota Department of Natural Resources (2007b) Minnesota's list of endangered, threatened, and special concern species. Minnesota Department of Natural Resources, St. Paul. http://files. dnr.state.mn.us/natural_resources/ets/endlist.pdf. Accessed 4 Jan 2008

Minnesota Department of Natural Resources (2008) Minnesota DNR Website. http://www.dnr.state.mn.us. Accessed 5 Feb 2008

Nekola JC (2002) Effects of fire management on the richness and abundance of central North American grassland snail faunas. Anim Biodivers Conserv 25(2):53-66

New TR (ed) (1993) Conservation biology of the Lycaenidae. IUCN, Gland

New TR, Pyle RM, Thomas JA et al (1995) Butterfly conservation management. Annu Rev Entomol 40:57-83. doi:10.1146/ annurev.en.40.010195.000421

Oates MR (1995) Butterfly conservation within the management of grassland habitats. In: Pullin AS (ed) Ecology and conservation of butterflies. Chapman \& Hall, London, pp 98-112

Panzer R, Schwartz MW (1998) Effectiveness of a vegetation-based approach to insect conservation. Conserv Biol 12:693-702. doi: 10.1046/j.1523-1739.1998.97051.x

Parmesan C (1996) Climate and species' range. Nature 382:765-766. doi: $10.1038 / 382765 \mathrm{a} 0$

Pellet J (2008) Seasonal variation in detectability of butterflies surveyed with Pollard walks. J Insect Conserv 12:155-162. doi: 10.1007/s10841-007-9075-8

Poiani KA, Merrill MD, Chapman KA (2001) Identifying conservation-priority areas in a fragmented Minnesota landscape based on the umbrella species concept and selection of large patches of natural vegetation. Conserv Biol 15:513-522. doi:10.1046/j. 1523-1739.2001.015002513.x

Pollard E, Eversham BC (1995) Butterfly monitoring 2-interpreting the changes. In: Pullin AS (ed) Ecology and conservation of butterflies. Chapman \& Hall, London, pp 23-36

Pollard E, Yates TJ (1993) Monitoring butterflies for ecology and conservation. Chapman \& Hall, London

Powell AFLA, Busby WH, Kindscher K (2007) Status of the regal fritillary (Speyeria idalia) and effects of fire management on its abundance in northeastern Kansas, USA. J Insect Conserv 11:299-308. doi:10.1007/s10841-006-9045-6

Pryke SR, Samways MJ (2001) Width of grassland linkages for the conservation of butterflies in South African afforested areas. Biol Conserv 101:85-96. doi:10.1016/S0006-3207(01)00042-8

Pullin AS (1996) Restoration of butterfly populations in Britain. Restor Ecol 4:71-80. doi:10.1111/j.1526-100X.1996.tb00109.x

Robertson PA, Clarke SA, Warren MS (1995) Woodland management and butterfly diversity. In: Pullin AS (ed) Ecology and conservation of butterflies. Chapman \& Hall, London, pp 113-122

Royer RA (2003) Butterflies of North Dakota: an atlas and guide, 2nd edn. Minot State University, Minot

Saarinen K, Lahti T, Marttila O (2003) Population trends of Finnish butterflies (Lepidoptera: Hesperioidea, Papilionoidea) in 19912000. Biodivers Conserv 12:2147-2159. doi:10.1023/A:10241 89828387

Samson F, Knopf F (1994) Prairie conservation in North America. Bioscience 44:418-421. doi:10.2307/1312365

Sands DPA, New TR (2002) The action plan for Australian butterflies. Environment Australia, Canberra

Schlicht D (1997a) Population monitoring for prairie butterflies in Minnesota. Report to the Minnesota Department of Natural Resources, St. Paul. http://files.dnr.state.mn.us/eco/nongame/ projects/consgrant_reports/19961996_schlicht.pdf. Accessed 5 Feb 2008 
Schlicht D (1997b) Surveys for the Dakota Skipper in Minnesota. Report to the Minnesota Department of Natural Resources, St. Paul. http://files.dnr.state.mn.us/eco/nongame/projects/consgrant_ reports/1997/1997_schlicht.pdf. Accessed 5 Feb 2008

Schlicht DW (2001) The decline of the Arogos skipper (Atrytone arogos) at Prairie Coteau in Pipestone County, Minnesota. In: Bernstein N, Ostrander L (eds) Proceedings of the seventeenth North American Prairie conference: seeds for the future, roots of the past. North Iowa Area Community College, Mason City, pp 197-200 http://digicoll.library.wisc.edu/cgi-bin/EcoNatRes/Eco NatRes-idx?type $=$ div \&did=ECONATRES.NAPC17.DSCHLICHT \&isize=text Accessed 5 Feb 2008

Schlicht DW (2003) Observations on the status of the Dakota Skipper at Prairie Coteau in Pipestone County, Minnesota. In: Ford S (ed) Proceedings of the 18th North American Prairie conference: promoting prairie. Truman State University Press, Kirksville, pp 213-216

Schlicht DW, Orwig TT (1998) The status of Iowa's Lepidoptera. J Iowa Acad Sci 105(2):82-88

Schlicht D, Saunders M (1993) Completion of status surveys for the Dakota skipper (Hesperia dacotae) and the poweshiek skipper (Oarisma poweshiek) in Minnesota. Report to the Minnesota Department of Natural Resources, St. Paul. http://files.dnr. state.mn.us/eco/nongame/projects/consgrant_reports/1993/1993_ schlicht_saunders.pdf. Accessed 5 Feb 2008

Schlicht D, Saunders M (1995) Completion of status surveys for the Dakota skipper (Hesperia dacotae) and the poweshiek skipper (Oarisma poweshiek) in Minnesota. Report to the Minnesota Department of Natural Resources, St. Paul. http://files.dnr.state.mn.us/eco/nongame/projects/consgrant_ reports/1993/1993_schlicht.pdf. Accessed 5 Feb 2008

Schlicht DW, Downey JC, Nekola JC (2007) The butterflies of Iowa. University of Iowa Press, Iowa City

Selby G (2006) Effects of grazing on the Dakota skipper butterfly; prairie butterfly status surveys 2003-2005. Report to the Minnesota Department of Natural Resources, St. Paul. http:// files.dnr.state.mn.us/eco/nongame/projects/consgrant_reports/ 2006/2006_selby.pdf. Accessed 5 Feb 2008

Selby G, Glenn-Lewin DC (1989) A systematic inventory, population monitoring program, and ecological study of rare Lepidoptera at the Prairie Coteau Scientific and Natural Area (SNA), Pipestone County, Minnesota. Report to the Minnesota Department of Natural Resources, St. Paul. http://files.dnr.state.mn.us/eco/ nongame/projects/consgrant_reports/1989/1989_glenn-lewin_ selby.pdf. Accessed 5 Feb 2008

Selby G, Glenn-Lewin DC (1990) An ecological study of the plant/ butterfly associations and their response to management, at the Prairie Coteau Scientific and Natural Area (SNA), Pipestone County, Minnesota. Report to the Minnesota Department of Natural Resources, St. Paul. http://files.dnr.state.mn.us/eco/ nongame/projects/consgrant_reports/1990/1990_glenn-lewin_ selby.pdf. Accessed 5 Feb 2008

Shuey JA (2005) Assessing the conservation value of a complementary system of habitat reserves relative to butterfly species at risk and divergent populations. Am Midl Nat 153:110-120. doi: 10.1674/0003-0031(2005)153[0110:ATCVOA]2.0.CO;2

Swengel AB (1996) Effects of fire and hay management on abundance of prairie butterflies. Biol Conserv 76:73-85. doi: 10.1016/0006-3207(95)00085-2

Swengel AB (1997) Habitat associations of sympatric violet-feeding fritillaries (Euptoieta, Speyeria, Boloria) (Lepidoptera: Nymphalidae) in tallgrass prairie. Great Lakes Entomol 30:1-18

Swengel AB (1998) Effects of management on butterfly abundance in tallgrass prairie and pine barrens. Biol Conserv 83:77-89. doi: 10.1016/S0006-3207(96)00129-2
Swengel AB (2001) A literature review of insect responses to fire, compared to other conservation managements of open habitats. Biodivers Conserv 10:1141-1169. doi:10.1023/A:1016 683807033

Swengel AB, Swengel SR (1997) Co-occurrence of prairie and barrens butterflies: applications to ecosystem conservation. J Insect Conserv 1:131-144. doi:10.1023/A:1018495428991

Swengel AB, Swengel SR (1999a) Observations on prairie skippers (Oarisma poweshiek, Hesperia dacotae, H. Ottoe, H. leonardus pawnee, and Atrytone arogos iowa) (Lepidoptera: Hesperiidae) in Iowa, Minnesota, and North Dakota during 1988-1997. Great Lakes Entomol 32:267-292

Swengel AB, Swengel SR (1999b) Observations on Schinia indiana and Schinia lucens in the midwestern United States (Lepidoptera: Noctuidae). Holarct Lepid 6:11-21

Swengel AB, Swengel SR (1999c) Timing of Karner Blue (Lepidoptera: Lycaenidae) larvae in spring and adults in spring and summer in Wisconsin during 1991-1998. Great Lakes Entomol 32:79-95

Swengel AB, Swengel SR (2001a) A ten-year study of the status and trend of the regal fritillary Speyeria idalia Lepidoptera: Nymphalidae) in Wisconsin, USA. Great Lakes Entomol 34(1):111-128

Swengel AB, Swengel SR (2001b) A ten-year study to monitor populations of the regal fritillary, Speyeria idalia, (Lepidoptera: Nymphalidae) in Wisconsin, USA. Great Lakes Entomol 34(2):97-115

Swengel AB, Swengel SR (2005a) Long-term population monitoring of the Karner Blue (Lepidoptera: Lycaenidae) in Wisconsin, 1990-2004. Great Lakes Entomol 38:107-134

Swengel AB, Swengel SR (2007) Benefit of permanent non-fire refugia for Lepidoptera conservation in fire managed sites. J Insect Conserv 11:263-279. doi:10.1007/s10841-006-9042-9

Swengel SR, Swengel AB (2005b) Spatial synchrony in Wisconsin Karner blue (Lepidoptera: Lycaenidae) populations. Great Lakes Entomol 38:135-154

Thomas JA (1983) A quick method for estimating butterfly numbers during surveys. Biol Conserv 27:195-211. doi:10.1016/00063207(83)90019-8

Thomas JA (1984) Conservation of butterflies in temperate countries: past efforts and lessons for the future. In: Vane-Wright RI, Ackery PR (eds) The biology of butterflies. Princeton University Press, Princeton, pp 333-353

Thomas JA (1995) The ecology and conservation of Maculinea arion and other European species of large blue butterfly. In: Pullin AS (ed) Ecology and conservation of butterflies. Chapman \& Hall, London, pp 180-197

Thomas CD, Wilson RJ, Lewis OT (2002) Short-term studies underestimate 30-generation changes in a butterfly metapopulation. Proc R Soc Lond B: Biol Sci 269:563-569. doi:10.1098/ rspb.2001.1939

Thomas JA, Telfer MG, Roy DB et al (2004) Comparative losses of British butterflies, birds and plants and the global extinction crisis. Science 303:1879-1881. doi:10.1126/science.1095046

TNC (The Nature Conservancy) (1988) Minnesota chapter preserve guide. The Nature Conservancy, Minnesota Chapter, Minneapolis

TNC (The Nature Conservancy) (1994) Minnesota chapter preserve guide. The Nature Conservancy, Minnesota Chapter, Minneapolis

TNC (The Nature Conservancy) (2008) The Nature Conservancy Minnesota Chapter. http://www.nature.org/wherewework/north america/states/minnesota/index.html. Accessed 17 Mar 2008

van Swaay C, van Strien A (2005) Using butterfly monitoring data to develop a European grassland butterfly indicator. In: Kuehn E, Thomas JA, Feldmann R, Settele J (eds) Studies in the ecology and conservation of butterflies in Europe. Proceedings of the Conference held in UFZ Leipzig, 5-9th December, 2005, vol. 1: general 
concepts and case studies. Pensoft Publishers, Sofia, pp 106-108 van Swaay C, Warren M, Loïs G (2006) Biotope use and trends of European butterflies. J Insect Conserv 10:189-209. doi: 10.1007/s10841-006-6293-4

WAEG (World Almanac Education Group) (2002) World Almanac and Book of Facts 2002. World Almanac Books, New York

Warren MS (1993) A review of butterfly conservation in central southern Britain: I. Protection, evaluation, and extinction on prime sites. Biol Conserv 64:25-35
Wendt KM (1984) A guide to Minnesota Prairies. Minnesota Department of Natural Resources, Natural Heritage Program, St. Paul

Williams DW, Liebhold AM (2000) Spatial synchrony of spruce budworm outbreaks in eastern North America. Ecology 81:2753-2766 